\title{
ГУМАНИТАРНАЯ ЭКСПЕДИЦИЯ РЕЙНА ВИЛЛИНКА В МОЛОЧАНСКИЙ МЕННОНИТСКИЙ ОКРУГ. МЕЖДУ РЕКОНСТРУКЦИЕЙ И ЭМИГРАЦИЕЙ: ГОЛЛАНДСКАЯ ПОМОЩЬ УКРАИНЕ В 1922-1929 гГ.
}

\begin{abstract}
Ад ван де Штаай. Гуманитарная экспедиция Рейна Виллинка в Молочанский меннонитский округ. Между реконструкцией и эмиграцией: голландская помощь Украине 1922-1929 гг.

Усилия организации «Американская меннонитская помощь» по оказанию гуманитарной помощи голодающим в России в начале 1920-х гг. известны относительно широко. Гораздо менее пшроко известны аналогичные усилия голландских меннонитов, которые имели своей целью укрепление связей между голландскими и украинскими меннонитами. Во главе этих усилий стоял Рейн Виллинк, чьи письма родителям и отчеты Фредерику Флейшеру, секретарю Algemeene Commissie voor Buitenlandse Noden (Генерального комитета помощи нуждаюшимся за рубежом) легли в основу этой статьи. В то время как Американская меннонитская помощь оказывала содействие России в целом, голландские меннониты сконцентрировали свои усилия на помощи Молочанским колониям меннонитов. И хотя общий объем помощи голландских меннонитов своим единоверцам в России был скромным по сравнению с усилиями их североамериканских собратьев, для спасенньх, которые не эмигрировали из Молочаной колонии в 1920-х гг., он имел огромное значение.

Ключевые слова: голод на Украине 1921-1923 гг., голландская меннонитская помощь, Молочанские меннонитские колонии, Рейн Виллинк.
\end{abstract}

Ад ван де Штаай. Гуманітарна експедиція Рейна Віллінка до Молочанського менонітського округу. Між реконструкцією та еміграцією: голандська допомога Україні в 1922-1929 pp.

Зусилля організації «Американська менонітська допомога» 3 надання гуманітарної допомоги голодуючим у Росії на початку 1920-х pp. широко відомі. Набагато менш дослідженими є подібні намагання голландських менонітів, які мали на меті зміцнення зв'язків між голландськими та українськими общинами. На чолі цих дій стояв Рейн Віллінк, чиї листи батькам і звіти Фредеріку Флейшеру, секретарю Algemeene Commissie voor Buitenlandse Noden (Генерального комітету допомоги нужденним за кордоном), покладено в основу цієї статті. У той час як «Американська менонітська допомога» сприяла Росії в цілому, голландські меноніти сконцентрували свої зусилля на підтримці Молочанських колоній менонітів. I хоча загальний обсяг допомоги голландських менонітів своїм одновірцям у Росії був скромнішим порівняно із зусиллями ïx північноамериканських побратимів, для всіх врятованих від голоду, що не емігрували з Молочанської колонії в 1920-х рp., він мав величезне значення.

Ключові слова: голод на Україні 1921-1923 pp., голландська менонітська допомога, молочанські менонітські колонії, Рейн Віллінк.

Ad van de Staaij. Rhein Willinks humanitäre Expedition in den Molochansky Mennonite District. Zwischen Wiederaufbau und Auswanderung: Niederlāndische Hilfe für die Ukraine 1922-1929.

Die Bemūhungen der amerikanischen American Mennonite Relief Organisation um in Russland in den frühen 1920er Jahren Hungerhilfe zu bieten, sind relativ bekannt. Das gilt nicht für die gleichzeitige Maßnahmen der niederländischen mennonitischen Taufgesinnte Hilfe, die ursprünglich nur die Absicht hatten, die Beziehungen zwischen niederländischen und ukrainischen Mennoniten zu stärken. Diese Aktionen wurden von Rein Willink geleitet. Seine Briefe an seine Eltern und Berichte an Frederik Fleischer, den Sekretär der Algemeene Commissie voor Buitenlandsche Nooden (Generalkomitee für ausländische Bedürfnisse), sind die Hauptquellen für diesen

\footnotetext{
${ }^{1} 3$ об’іктивних обставин стаття друкується у редакції автора.

${ }^{2}$ Автор висловлюе подяку Петеру Леткеману, Адріану Плаку, Наталії Венгер, Олександру Безносову та Піту Віссеру за інформаційну підтримку.
}

(C) Ад ван де Штаай, 2020 
Artikel. Während die amerikanische mennonitische Hilfe ihre Hilfe auf ganz Russland richtete, beschränkten sich die niederländischen Mennoniten auf die mennonitische Kolonie Molotschna. Obwohl der Gesamtbeitrag der niederländischen Mennoniten zu Ukrainischen Glaubensgenossen im Vergleich zu dem der Nordamerikaner bescheiden war, war er aus Sicht der Mennoniten, die in den 1920er Jahren nicht aus Molotschna auswanderten, dennoch sehr wichtig.

Schlüsselwörter: Hungersnot in der Ukraine 1921-1923, mederländische mennonitische Hilfe, molochanische mennonitische Kolonien, Rein Willink.

Ad van de Staaij. Rhine Willink's humanitarian expedition to the Molochansky Mennonite District. Between reconstruction and emigration: Dutch aid to Ukraine 1922 - 1929.

The efforts by the American Mennonite Relief organization to provide famine relief to Russia in the early 1920s are relatively well known. Far less known are the actions of Dutch Mennonite relief efforts at the same time, which were intended to strengthen the ties between Dutch and Ukrainian Mennonites. These actions were led by Rein Willink, whose letters to his parents and reports to Frederik Fleischer, the secretary of the Algemeene Commissie voor Buitenlandsche Nooden (General Committee for Foreign Needs), are the main source for this article. Whereas the American Mennonite Relief directed its aid to the whole of Russia, the Dutch Mennonites restricted themselves to the Mennonite colony of Molochna. Although the total contribution of Dutch Mennonites to Russian co-religionists was modest compared to that of the North Americans, it was nonetheless very important when viewed from the perspective of Mennonites who did not emigrate from Molochna in the 1920s.

Key words: famine in Ukraine 1921-1923, Dutch Mennonite aid, Molochan Mennonite colonies, Rem Willink.

$$
\begin{array}{r}
\text { «охоже, голландцев больше интересует бизнес, } \\
\text { чем помощь голодающим» } \\
\text { Кристиан Крейбель, } 18 \text { апреля } 19222 .
\end{array}
$$

«Нам вас послал Господь Бог!» Анна Берг, 1 мая 1922 г.

В январе 1922 г. пять голландских меннонитов отправились из Нидерландов в Молочанский меннонитский округ, имевший население около 30000 человек и представлявший собой крупнейший округ меннонитов на Украине. С конца 1921 г. тысячи его жителей находились на грани полного истощения из-за голода, охватившего юг России. Голландская группа, состоящая из двух мужчин и трех женщин, являлась частью гуманитарной экспедиции, целью которой было обеспечить своевременное распределение партий продовольствия, одежды и медикаментов среди нуждающихся. Возглавлял группу Рейн
Виллинк, сын крупного предпринимателя из Винтерсвейка (провинция Гелдерланд). Спустя несколько месяцев их миссия была выполнена: к Пасхе 1922 г. гуманитарные поставки были распределены, и большинство обитателей меннонитской колонии были спасены. Эта инициатива, по большей части забытая историками, не столь широко известна, как история организации «Американская меннонитская помощь» (АМП) или деятельность Hollandsch Doopsgezind Emigranten Bureau (Бюро эмиграции голландских меннонитов) ${ }^{3}$. Однако путевые заметки, отчеты и письма 4 Рейна Виллинка однозначно дают понять, что

\footnotetext{
${ }^{3}$ Ори Миллер (Orie Miller) не упоминает Виллинка в своей истории Амераканской меннонитской помощи [13]. Джон Тэвс (John Toews) несколько раз ссылается на Рейна Виллинка, но исключельно в контексте темы реконструкции и эмиграции. Тэвс представляет дело так, будто меннониты как на Хортице, так и на Молочной были спасены благодаря американской продовольственной помощи от организации «Американская меннонитская помощь» [21, р. 85-86]. Жаннет ван Воерден (Jeannet van Woerden) уделила голландской миссии несколько больше внимания, но в основном в качестве предыстории Бюро эмиграции голландских меннонитов [24]. Путевые заметки Виллинка являются ценным дополнением к дневникам современников, таких как Анна Берг (Anna Baerg) [1], Peter Dyck [3] и Christian Krehbiel [2]. Еще одним ценным источником информации является публикация документов, обнаруженных в статье John Toews [21]. Эти источники дополняют историю Виллинка контекстом, отражающим отношение голодающих к помощи, поступившей весной 1922 г., напряжение, возникшее между американщами и голландщами, а также изощренную игру, которая велась с неопытными, но далеко не наивными, большевистскими властями. Я надеюсь опубликовать материалы Рейна Виллинка в рамках Manuscripta Mennonitica.

${ }^{4}$ Оригиналы путевых заметок и писем родителям Виллинка хранятся в семейном архиве. Оригиналы отчетов и копии части путевых заметок хранятся в государственном архиве в Амстердаме [20]. Первая часть путевьх заметок (Винтерсвейк - Варшава) утеряна. Я бы хотел поблагодарить Робберта Виллинка и Роджера Бригтса за доступ к семейным архивам.
} 
голландская гуманитарная операция весной 1922 г. была так же тщательно продумана и в действительности лучше организована и более эффективна, чем развернутые американцами бесплатные столовые, где наиболее бедные из меннонитов могли поесть раз в день.

Виллинк вернулся в Нидерланды в июле, когда голод немного спал, для предоставления промежуточного отчета. Однако уже к сентябрю он вернулся в Россию. Голландские меннониты, которых он представлял, явно хотели оказать помощь и в проведении восстановительных работ. Однако вокруг их истинных намерений возник некоторый налет таинственности. Помощь голодающим была инициирована в контексте так называемого Gemeentedagbeweging - движения духовного и этического возрождения голландских меннонитов. Однако примечательно, что ни Рейн Виллинк, ни Фредерик Флейшер, священникменнонит из Винтерсвейка, который стоял за организацией всей кампании помощи голодающим, не принадлежали к этому движению. Как Виллинк, так и Флейшер всеми силами старались отговорить жителей Молочанской колонии от эмиграции, вместо этого агитируя их за восстановление колонии в условиях советской власти. Их позиция вызывает ряд вопросов. Была ли помощь голодающим мотивирована исключительно добросердечием меннонитов? Или к помощи в восстановлении меннонитских колоний были примешаны и корыстные материальные интересы?

Данная статья описывает обстоятельства, в которых состоялась экспедиция Виллинка, в контексте обсуждения в Нидерландах таких вопросов, как голод, эмиграция и восстановление. Она посвящена в основном Рейну Виллинку и его путевым заметкам, прослеживающим его жизнь в 1922 г. История Виллинка проливает свет на отношения между голландскими меннонитами и их украинскими собратьями вплоть до 1938 г., когда голландские меннониты прекратили собирать пожертвования для своих единоверцев в Советском Союзе. В статье также отражена комплексная природа мотивов, которые двигали Виллинком и Флейшером в их работе. Внимание уделено тому, как легко могут переплетаться интересы бизнеса и филантропические устремления.

Меннониты в беде: Нидерланды и Украина

В конце XIX в. небольшая группа меннонитов в Нидерландах начала выражать обе- спокоенность падением интереса к религиозной жизни. По их мнению, голландские меннониты стали слишком зажиточными и перестали ценить значение своей веры ${ }^{5}$. В целом голландские меннониты не уделяли достаточно времени размышлениям о духовном, переложили всю работу церкви на плечи священников и посещали церковные службы, только если проповедник обладал ораторским талантом [8, p. 11-20]. Казалось, что люди более не испытывали духовной потребности и перестали вносить вклад в жизнь своей религиозной общины, если не считать выплаты обязательных взносов. В 1917 г. несколько молодых богословов-меннонитов, вдохновленные опытом английских квакеров в Вудбруке ${ }^{6}$, решгили организовать национальный Gemeentedag - собрание религиозных общин. Организаторы надеялись, что собрание усилит веру его участников и затем получит практическое воплощение в образовании рабочих групп для изучения Библии, работе с молодежью, непротивленчестве или связях с веруюшими в других странах. Проведенное в 1917 г. Gemeentedag оказалось успешным, и организаторы решили проводить подобные собрания ежегодно [20,389/6].

В это же время меннониты на Украине столкнулись с совершенно иными проблемами, напрямую связанными с революционными событиями в России. После Февральской революции 1917 г. банды молодых анархистов орудовали на юге страны, захватывая участки земли, угрожая богатым землевладельцам и силой отбирая ценное имущество. В ответ на это весной 1918 г., после заключения мирного соглашения между Украиной и Германией, немецкие солдаты начали обучение групп молодых меннонитов с целью создания подразделений самообороны (Selbstschutzgruppen) для защиты их общин от бесчинств анархистов. Несколько влиятельных землевладельцев воспользовались ситуацией, чтобы вернуть себе земли, отобранные у них годом ранее. Однако, когда война на Западном фронте закончилась в ноябре 1918 г., армии Германии и Австро-Венгрии были вынуждены покинуть Украину. Тогда подразделения самообороны меннонитов вошли в состав войск генерала Деникина, так называемую Белую армию, внутри которой они составили два батальона. В последовавшем хаосе власть ненадолго захватили большевики,

\footnotetext{
${ }^{5}$ Хотя в английском и русском используется термин «меннониты», в Нидерландах эта группа чаще обозначается термином «Doopsgezinde».

${ }^{6}$ Центр встреч международного молодежного движения, которое, помимо прочего, стремилось дополнить либеральное и одновременно духовное христианство практицеским содержанием за счет общественной работы.
} 
затем эту территорию пробовала завоевать армия Деникина, совершая при этом многочисленные зверства против еврейского населения, обедневших крестьян и анархистов. В сентябре 1919 г. казалось, что Деникин одержит верх. Но затем баланс сил вновь переменился. К концу осени войска Деникина были разгромлены, а их остатки бежали на восток. Крестьяне и анархисты начали мстить тем, кто ранее пытался уничтожить их. Среди тех, на кого обрушился их гнев, были землевладельцы в четырех зажиточных меннонитских колониях: Заградовка, Языково, Хортица и Молочанск. Частично в ответ на сопротивление, оказанное группами самообороны меннонитов, банды анархистов грабили дома, насиловали женщин, жгли сельхозпостройки и убили около 700 человек [10, p. 158-159; 11; $12 ; 14$, p. $71-76 ; 17 ; 19]$.

Посреди всего этого хаоса несколько сотен меннонитов смогли спастись и нашли убежище в Германии. Оставшиеся меннониты искали возможности покинуть Россию. В конце 1919 г. члены Молочанской колонии меннонитов отправили трех мужчин на запад для изудения перспектив эмиграции. В начале 1920 г. те прибыли в Нидерланды [22, p. 118 $129 ; 23$, p. 179, 181-182, 185, 191].

Голландские меннониты были хорошо осведомлены обо всех этих событиях благодаря регулярным репортажам в их еженедельной газете Zondagsbode 7 . На собрании религиозных общин Gemeentedag в 1920 г. представители украинских меннонитов рассказали о тяготах, переживаемых их общинами. Как результат, лидеры Gemeentedagen, такие как Тиерд Хилкема, священник из г. Гитхорн, начали сбор денег и одежды для беженцев, нашедших приют в Германии. Однако эти усилия были признаны недостаточными. В конце 1920 г. был сформирован комитет поддержки в составе Тиерда Хилкема, Абрахама Куйпера (священника из Амстердама), Арьена Биннертса (священника из Харлема), Дю Воелинга (сотрудника почтовой службы из Зе- еландии) и Фредерика Флейшера, священника из Винтерсвейка $[20,1118 / 017$ : отчет от 10 декабря 1920 г. $]^{8}$. Целью комитета поддержки был сбор денежных средств и одежды для иностранных организаций помощи меннонитам, таких как «Американская меннонитская помощь», которые старались организовать экстренные поставки помощи непосредственно на Украину и поддерживать беженцев в Германии. В его задачи не входило учреждение независимой голландской гуманитарной организации. Чтобы стимулировать пожертвования, Хилкема написал небольшой очерк о недавней истории украинских меннонитов [11] $]^{9}$ Книга Хилкема вышла в декабре 1920 г., и вскоре после этого он отправился в Англию с Бенджамином Анрухом, одним из представителей украинских меннонитов, с целью убедить своих знакомых из квакерских кругов расшиияять возможности для эмиграции ${ }^{10}$.

Между тем сотрудники американских организаций помощи меннонитам смогли попасть на Украину под защитой русского генерала Петра Врангеля. Однако в 1920 г. войска Врангеля были разбиты группами анархистов и силами Красной армии, и большинство американцев вынуждены были ретироваться. Вскоре после этого большевики разбили анархистов и отрезали доступ в те районы. С того момента информация о том, что происходит в регионе, перешла в разряд догадок, хотя иностранцы предполагали, что, когда доступ будет снова открыт, потребность в помощи при восстановлении селений будет высока $[13$, p. $90-116]$.

Со временем голландские меннониты поняли, что одного сбора помощи, которая затем будет распределяться иностранными организациями, недостаточно. Поэтому необходимо создать независимую голландскую организацию помощи меннонитам. Таким образом, весной 1921 г. голландские меннониты выработали два направления помощи Украине: одно заключалось в изучении возможностей для эмиграции и помощи бежен-

\footnotetext{
${ }^{7}$ Священник Тен Кейт из г. Апелдорн следил за сообщениями в международной меннонитской прессе и регулярно готовил подборки из наиболее важных из них. В 1920 г. он познакомился с Хейнрихом Варкентином, меннонитом и сотрудником укранского консульства в Гааге, который стал для него ценным источником информации.

${ }^{8}$ Флейшер не входил в состав упредителей Gemeentedagen, но был приглашен благодаря своей репутапии отличного организатора. Он создал национальную ассоциацию домовладений (Зеленый крест) и в 1924 г. служил директором ее центрального офиса, руководившим деятельностью десяти региональных ассопиаций [2.1].

9 Этот непредвзятый обзор до сих пор представляет большую ценность, потому что включает несколько свидетельств одевидцев, вероятно, записанных с устных рассказов Анруха и беженцев, осевших в Германии.

${ }^{10}$ Благодаря связям Хилкема в квакерских кругах они были представлены влиятельным британским политикам. Эмиграция в Южную Африку и Австралию оказалась невозможна, зато Канада представлялась перспективным направлением. В то время там проходили выборы, и Макензи Кинг, кандидат от Либеральной партии, который благоволил меннонитам, имел хорошие шансы стать премьер-министром [20, 1118/017: отчет от 14 февраля 1921 г.].
} 
цам, а второе состояло в подготовке к помощи в проведении восстановительных работ в тех районах, откуда меннониты не могли эмигрировать или же там, где они предпочли бы остаться. Последнее требовало более мощной организации. В феврале 1921 г. комитет поддержки был преобразован в Algemeene Commissie voor Buitenlandse Noden (Генеральный комитет помощи нуждающимся за рубежом). 11 июля пастор Биннертс разместил в газете Zondagsbode объявление с призывом к «молодым энергичным меннонитам», которые бы хотели обеспечить доставку одежды и лекарств на Украину. Он описал эту миссию как «доброе и важное дело во имя любви. Возможно, она не будет лишена опасности, но она определенно принесет глубокое чувство удовлетворения» ${ }^{11}$.

На объявление откликнулись пять человек, из них были отобраны два. Первым был Якоб Коекебаккер, известный священник из Аарденбурга. Коекебаккер выступал с лекциями на различных Gemeentedagen и ранее уже пытался организовать помощь для единоверцев в Бельгии, которые столкнулись с тяготами в годы Первой мировой войны. Вторым кандидатом, известным только Флейшеру, стал Рейн Виллинк, 32-летный сын крупного предпринимателя из Винтерсвейка. Виллинк был холост и, соответственно, свободен.

\section{Голод}

Между тем, весной 1921 г. юг России поразила массовая гибель посевов. На фоне истощения ресурсов из-за войны и последовавшей за ней анархии это привело к серьезной нехватке продуктов питания и голоду во многих частях страны. И хотя большевистские власти пытались скрыть голод от остального мира, вскоре они вынуждены были обратиться за иностранной помощью. В конце июля известный русский писатель Максим Горь- кий, проживавший в то время за границей, выступил с публичным призывом о помощи голодающим ${ }^{12}$. На него быстро откликнулись Фритьоф Нансен, норвежский полярный исследователь, который в это время являлся верховным комиссаром Лиги Наций по вопросам беженцев, и Герберт Гувер, глава Американской администрации помощи (АРА), которая уже занималась оказанием гуманитарной помощи в Европе с конца 1916 г. ${ }^{13}$ В августе они договорились с советскими властями о предоставлении продовольственной помощи. Однако эти договоренности не распространялись на Украину, которая тогда формально являлась независимой страной. Поскольку новые большевистские власти держали тот регион в изоляции, масштабы поразившего его голода были неизвестны внешнему миру. Между тем голландские меннониты продолжали собирать материальную помощь для своих единоверцев на Украине и продумывали различные возможные способы войти с ними в контакт.

Когда голландскому Algemeene Commissie voor Buitenlandse Noden стало известно, что Алвин Дж. Миллер, директор Американской меннонитской помощи, направился в Москву, чтобы договориться о получении доступа в пораженные голодом районы, комитет решил отправить Якоба Коекебаккера вместе с Миллером, чтобы заручиться разрешением советских властей отправить помощь на Украину. Коекебаккер отправился в путь с несколькими ящиками медикаментов и прибыл в Москву 17 сентября. После встречи с Миллером они были приняты Максимом Литвиновым (замминистра иностранных дел) и Львом Каменевым (вице-председателем Центральной комиссии помощи голодающим при ВЦИК (Помгол). Поскольку большевики не доверяли американцам, они решили «столкнуть Миллера и Коекебаккера лбами». Подписанный до-

\footnotetext{
${ }^{11}$ Предупреждение о возможной опасности не было пустыми словами. Клейтон Крац, молодой сотрудник организации помощи меннонитам из Пенсильвании, остался в регионе после отступления войск Врантеля и пропал в последовавшем за этим хаосе. На протяжении 1921 г. было много спекулапий относительно того, жив ли он, однако с течением времени надежды на это угасали. De Zondagsbode писал об этой истории за две недели до публикации призыва пастора Биннертса (26 июня 1921 г.). Когда доступ в тот район был снова открыт, выяснилось, что Крац был арестован и казнен болышевиками в конце 1920 г.

${ }^{12}$ Большевики только что одержали победу в гражданской войне, но их поддержка внутри страны была крайне неустойчивой. Поскольку у них, как у революционеров, была плохая репутация за границей, призыв о помощи был бы интерпретирован как признак слабости, возможно, первый признак того, что большевистская власть терпит поражение. Шансы того, что помощь будет предложена без политических оговорок, были крайне малы. Горький симпатизировал революции, но критически относился к большевистским методам и поэтому был вынужден уехать за границ, в Италию. Поскольку он поддерживал хорошие контакты с европейскими гуманистами, его репутация не была запятнана сомнительными действиями большевистских властей. Именно поэтому Ленин и попросил его выступить с призывом о помощи. Горький не мог отказать Ленину в этой просьбе, поскольку, в конще концов, дело касалось спасения жителей России, а не только большевиков [16, р. 25-27].

${ }^{13}$ В 1916 г., когда Гувер был назначен главой этой организации, она носила название «Управление США по продовольственным ресурсам».
} 


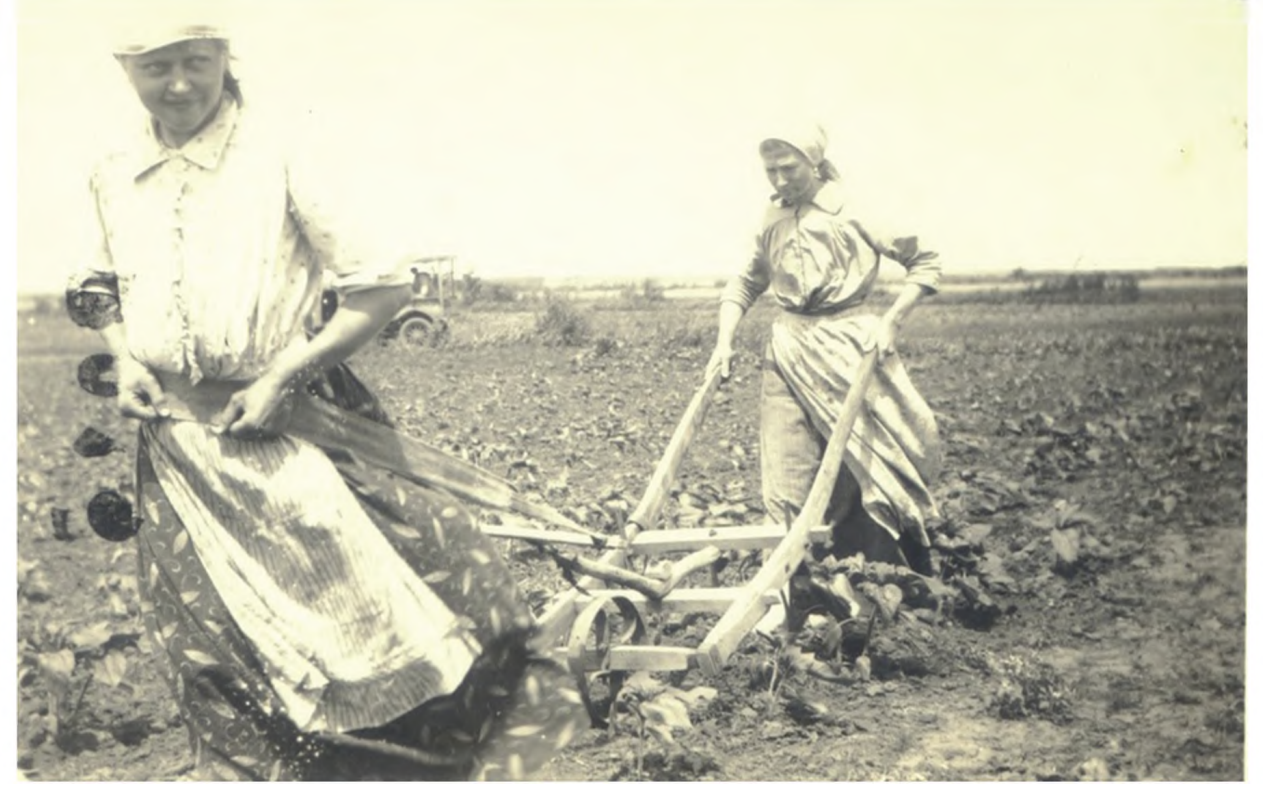

Рис. 1. Женщины вцрягались в плуг пз-за вехватки лошадей. Когда начался посев весной 1922 г., в болыпанстве деревень не было рабочах лопадей, так как почти все они были съедены во время голода. На фото: сестры Пеннер за работой в поле; везадолго до этого они были спасены от голода прибывшей продовольственной помощью (фото Крейбеля)

говор предоставлял доступ на Украину голландским меннонитам, а американцы могли к ним присоеднниться ${ }^{14}$. Таким образом, спустя почти год, доступ к меннонитским колониям был наконец восстановлен. Однако в соглашенит оговаривалось, что никакие групाы в регионе не должны были пользоваться привилегиями при распределении помопи. Вместе с этим гуманктарные организации имели право сконщентрировать свои усилия в каком-ли60 конкретном районе. Algemeene Commissie voor Buitenlandse Noden остановился на районе вокруг Молочанска, где было сконщентрировано наибольшее количество меннонитов ${ }^{15}$.

Коекебаккер был настолько потрясен историями о страданиях голодающих, что по во3врапения на родину в начале октября выступил с эмоциональным обрапением в голландской прессе. В статье под заголовком «Молба о помощи. Шесть миллионов детей умиракот от голода!» он напнсал: «Вчера я вернулся из Москвы. Сегодня я обращағось с мольбой к голландцам. То, что происходит сейчас в России, ужасно. Советское правительство заявило, что одной только прошлой зимой песть миллионов детей (по консервативным оценкам) страдали от голода. Если иностранная помошь не постушит, они погибнут от истощения».

Коекебаккер ссылался на кампанию, развернутую комктетом голландских меннонитов, но также запустил и собственную кампанию по сбору средств, предлагая направлять их ему на счет, «дя облегчения процесса администрирования» (Algemeen Handelsblad, Nieuwsblad van Friesland, Tribune (4 октября 1921 г.); Het Volk (6 октября 1921 г.); а также в de Zondagsbode ( 9 октября 1921 г.). Последнее вызвало немало вотросов в Algemeene Commissie voor Buitenlandse Noden, поскольку Коекебаккер действовал по собственной инициативе и не посоветовавцпис с коллега-

\footnotetext{
${ }^{14}$ Поскољку в августе Миллер передал Американскуюо менвонитскуюо помощь под контроль АРА, ов ве был уверев, был ли он уполномоден подшисывать соглашение по Украине, которое было составлено по модели нансеновского соглашення. Поэтому Коекебаккер подписал документ в вернулся в Голландню, а Миллер должев был согласовать

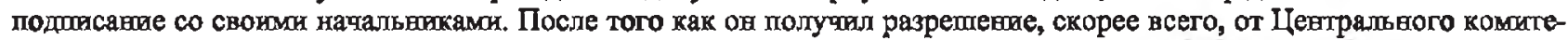
та мевнонитов, он тағоке подписал соглашение и доставил его копио в Algemeene Commissie voor Buitenlandse Noden, когда он был в Голшандия в ноябре.

15 Вследстве контактов с Studiencommission комитет подтержкн внутри Algemeene Commissie voor Buitenlandse Noden с самого начала сконцентрировапся на проведенин восстановительных работ на Украине, а не на помощи менноңитам в других пастях Россит [20, 1118/017: протокол от 12 декабря 1920 г., 14-2-1921; 1118/018: протоколы ог 1 иоля 1921 г. в 10 июля 1921 г.].
} 
ми. Более того, создавалось впечатление, что он стремился помочь, скорее, русским детям, а не украинским меннонитам. Последовал обмен нервными телеграммами и письмами между членами комитета в отчаянных попытках созвать экстренное собрание. Поразительно, что члены комитета, которые обычно тщательно вели протоколы своих собраний, не составили письменного отчета о встрече 16 октября. Но эта встреча оказалась результативной. Когда на следуюпий день эмоции улеглись, дискуссия стала более конструктивной. Оказалось, что Коекебаккер интерпретировал свою миссию как задание заключить соглашение о помощи не только для меннонитов. Теперь комитету предстояло решить, будут ли они оказывать общую или адресную помощь.

Поскольку Коекебаккер оказался первым представителем голландской гуманитарной организации, получившим доступ в Россию, члены комитета решили, что они постараются взять на себя руководящую роль в организации голландской помощи России, будут координировать деятельность двенадцати голландских гуманитарных организаций и создадут отдельный департамент для оказания помощи меннонитам. Однако остальные организации не согласились с таким решением, и через две недели комитет вернулся к первоначальной цели оказания поддержки лишь своим единоверцам [20, 1118/005, Ag 127: отчет Коекебаккера); 1118/019, 022: собрание 17 октября 1921 г.]. Растущее осознание опасности массового голода на Украине отодвинуло первоначальные намерения содействия эмиграции и восстановительных работ на второй план ${ }^{16}$. Призыв Коекебаккера послужил импульсом для большого числа организованных меннонитами мероприятий, включая лотереи, кампании в школах и церквях, а также ряда индивидуальных инициатив в помощь «голодающей России». Их результатом стало значительное увеличение собранных средств. Весной того же года Algemeene Commissie voor Buitenlandse Noden рассма- тривал возможность направить собственную экспедицию на Украину, как только будет собрана сумма в 50000 гульденов. В то время, однако, члены комитета сомневались, что эта цель будет достигнута. Когда Коекебаккер отправился в Москву в сентябре, сумма собранных средств составляла всего лишь 18000 гульденов. Однако через месяц после его возвращения сумма пожертвований превысила отметку в 50000 гульденов. Последнее позволило начать планирование гуманитарной экспедиции. Коекебаккер не мог принять в ней участие, поскольку в нем нуждалась его паства. Тогда за дело взялся Рейн Виллинк [20, 1118/018: Протоколы собраний Algemeene Commissie Buitenlandse Noden, 9 ноября 1921 г.].

\section{Рейн Виллинк становится членом экспе-} диции

Рейн Корнелиус Якобс Виллинк родился в Винтерсвейке 15 января 1886 г. и там же был крещен в меннонитской церкви в 1906 г. Он был отпрыском местной меннонитской элиты: его отец был директором фабрики ситца. Будучи первенцем, Виллинк должен был стать преемником своего отца. Но он не смог закончить университетский курс в Делфте и получить диплом инженера, и отец решил передать свое дело другому сыну. Рейну пришлось искать другое занятие. В 1917 г., проработав на нескольких незначительных административных муниципальных должностях в Абкауде, Виллинк был назначен секретарем Управления топлива в Харлеме и осуществлял надзор за распределением угля в округе Кеннемерланд. Двумя годами позже он стал директором управления и занимал эту должность до 31 марта 1921 г., когда организация была распущена $[6$, p. $90 ; 20$, inv. $319 ; 21]$.

В различных документах Виллинк описывается как спокойный, жизнерадостный человек с широкими взглядами на мир. Он был членом культурного кружка в Харлеме и пристально следил за новостями в газетах и журналах, а это означало, что он был хорошо осведомлен о ситуации в России. Поскольку он

\footnotetext{
${ }^{16}$ Получить надежную информацию из пораженньх голодом районов было непросто. Почтовое сообщение с Россией было восстановлено только в мае 1921 г., но и тогда необходимо было учитывать проблему цензуры (De Telegraaf (21 мая 1921 г.). Беженцы могли обладать актуальной информацией, но с конца 1920 г. ее почти не поступало. Четыре беженца приехали из Германии в Нидерланды, один из которьх (Лепп) оказался в Винтерсвейке. Возможно, он получал какую-то корреспонденцию. Флейшер поднимал эти вопросы на страницах De Zondagsbode. 16 октября 1921 г. он упоминает неурожай на юге и востоке России, который может затронуть меннонитов. 30 октября 1921 г. казначей Ван дер Влюгт представил подробный отчет о деньгах, поступающих для помощи «голодающим в России». 11 ноября 1921 г. Algemeene Commissie Buitenlandse Noden принял решение, что продовольственная помопь должна включать не только муку, а также жиры, углеводы и т.д. В номере De Zondagsbode от 27 ноября 1921 г. Флейшер выступил с обширным обращением, но и в нем он не упомянул возможный голод на Украине. В номерe De Zondagsbode от 3 декабря 1921 г. Ван дер Влюгт сообщил, что первая «партия продовольствия для юга России» будет скоро отправлена. Позже выяснится, что в это время в Молочанском округе не было голода.
} 
не испытывал интереса к женщинам, возможно, Виллинк уже осознавал, что он - гомосексуалист. Таким образом, когда пастор Биннертс в июле опубликовал свое обращение в Zondagsbode, Виллинк, не отягощенный семейными узами, откликнулся на него практически сразу.

Флейшер и Виллинк начали обсуждать, каким образом лучше организовать экспедицию. Тогда как Коекебаккер и Algemeene Commissie voor Buitenlandse Noden предлагали доставлять гуманитарную помощь по суше через Москву, Виллинк считал, что лучше отправить ее морем через Румынию или Болгарию. Виллинк полагал, что урон, нанесенный железным дорогам в России гражданской войной, делал железнодорожные перевозки ненадежными. Более того, многие части России все еще не были полностью под контролем большевиков. Поэтому, утверждал он, было бы лучше, чтобы ценный груз прошел максимально возможную часть пути через Европу, а его перемещение по территории Украины было бы сведено к минимуму. Комитет поручил ему это задание в сентябре, и Виллинк быстро согласился возглавить экспедицию на безвозмездной основе и приступил к подготовке [20, 1118/005/ Ag 139; 20, 1118/018].

Экспедиционная команда состояла из Виллинка, Д. Йонгенса (бухгалтера, который станет его правой рукой), двух медсестер и жены бухгалтера ${ }^{17}$. Виллинк должен был отправиться в путь первым и добраться до Харькова через Варшаву и Киев. Остальные участники экспедиции чуть позднее должны были направиться в Варну через Вену и оттуда сесть на пароход до Бердянска. В последнем пункте они планировали встретиться с Виллинком и вместе отправиться на Молочную [20, 1118/018]. На основании договоренности, заключенной между Коекебаккером и большевиками, участники гуманитарной экспедиции отправлялись на выполнение миссии со следующими указаниями [Там же]:

1) оказывать материальную помощь страдающему населению юга России, особенно в тех районах, где ограниченные ресурсы комитета могли принести максимальную пользу;

2) оказывать моральную поддержку меннонитским общинам в России и сообщать об их положении и нуждах родственным общинам. Действовать с целью заручиться большей поддержкой со стороны государственной власти.

Материальная помощь могла состоять из помощи голодающим, а также поддержки восстановительной работы. Моральная поддержка могла включать возможность эмиграции и обещание предоставить учебную литературу для школ или церквей.

Однако похоже, что Algemeene Commissie voor Buitenlandse Noden не доверял Виллинку до конца ${ }^{18}$. В ходе обсуждения указаний для экспедиции комитет подчеркивал, что ее руководитель должен быть «руководителем среди коллег, а не подчиненных», то есть он не должен был быть выше других участников экспедиции [20, 1118/018]. В ноябре комитет принял предложение сделать брата казначея Яна ван дер Влюгта одним из соруководителей экспедиции вместе с Виллинком. Ван дер Влюгт должен был обеспечить «хорошие отношения с нашими русскими братьями, которые так сильно пострадали». Однако в итоге Ван дер Влюгт остался дома.

«Летучий голландец» организует помощь голодающим

Виллинк покинул Нидерланды 17 января 1922 г., а затем переправился из Варшавы в Киев. Из Киева он направился в Харьков, столицу Советской Украины ${ }^{19}$. Он был в восторге от путешествия на поезде через заснеженные пейзажи, где все еще были видны последствия гражданской войны: лишь частично восстановленные железнодорожные мосты, сломанные локомотивы и разрушенные станции. Хотя сам Виллинк путешествовал с комфортом в отапливаемом купейном вагоне для дипломатов, он думал о простых пассажирах в плохо отапливаемых плацкартных вагонах. Среди его попутчиков были несколько колоритных персонажей, включая большевиков,

\footnotetext{
${ }^{17}$ Ожидалось, что медсестры Маартж Кат и Жаннет Вермаас будут оказывать медицинскую помощь жителям меннонитских колоний. Обе они сотрудничали с Красным Крестом и побывали на нескольких балканских фронтах во время войны. У четы Йонгенс был опыт работы в Соединенных Штатах и Британской Индии.

${ }^{18}$ Было ли это по причине того, что в свою бытность в Харлеме Виллинк не посещал Биннертса и меннонитскую церковь? Или из-за того, что он был слишком тесно связан с недавним новичком Флейшером, который только что встал во главе всего секретариата организации? В составе Algemeene Commissie Buitenlandse Noden секретариаты внутренних и внешних дел были поделены между Флейшером и Воелингом. Когда Воелинг решил уйти в отставку из-за болезни жены и растущего объема работы, энергичный Флейшер забрал его функции себе. Это означало, что в 1922 г. вся деятельность сосредоточилась в Винтерсвейке [6, p. 1].

${ }^{19}$ Виллинк вел своего рода путевой дневник, части из которого он отправлял своим родителям с припиской «не для публикации», поскольку он планировал выпустить книгу о своих путешествиях. Его путевые заметки, охватьвающие период с 20 января по 11 марта, занимают 64 странищы.
} 
которые добродушно потешались над западными странами, которые якобы испытывают страх перед коммунистами. Русские произвели впечатление на Виллинка не только тем, как по утрам они обтирались снегом, но и своими рассказами о событиях последних лет. Они оказались гораздо более цивилизованными людьми, чем он себе представлял. Виллинк был предупрежден о цензуре и репрессиях, и поэтому он нигде не указывал имен своих попутчиков. Чтобы не тревожить свою мать, он также избегал упоминания особенно шокирующих подробностей, таких как грабежи и убийства, которые все еще совершались в Молочанском округе, а также случаи смертей от брюшного тифа [3, p. 178-190].

В субботу 28 января Виллинк прибыл в Харьков, где его разметили в гостинице неподалеку от офисов гуманитарных организаций. Через два дня, 30 января, он посетил украинский офис Помгола. Поразительно, но на этих первоначальных переговорах речь шла не столько о скорой доставке продовольствия в Молочанскую колонию, сколько о возможности импорта голландских тракторов на Украину. Виллинк дал понять, что готов это организовать, но для этого понадобится гарантия в 5 млн золотых рублей. Вскоре после этого он написал Флейшеру: «Если будет решено внести депозит в 5 млн. золотых рублей, наш план может быть полностью выполнен» ${ }^{20}$. Частью этого «плана» было намерение Флейшера и Виллинка как можно скорее отправить в Молочанскую колонию группу экспертов по мелиорации для проведения там восстановительных работ. На тот момент Флейшер надеялся привлечь к реализации этого проекта голландских инвесторов, но для них необходимым условием было наличие государственных гарантий. Поскольку голландское правительство не хотело давать никаких гарантий, Виллинк должен был попытаться получить их от большевиков.

Через несколько дней к Виллинку присоединились украинские меннониты Гейнрих Корнельсен и Герхард Хардер. Последний из них станет проводником Виллинка на ближайшие месяцы. Все трое отправились поездом на Молочную. Через два дня они прибыли в Лихтенау (основная железнодорожная станция). Виллинк прибыл как раз вовремя, чтобы принять участие в важном собрании в Орлове, где лидеры меннонитов единодушно приняли решение начать подготовку к эмиграции [21, р. 392-395].

В последовавшие за этим дни Виллинк получил представление о последствиях гражданской войны и растущем голоде. Поскольку он был первым представителем западного мира, прибывшим в регион после того, как большевики победили в гражданской войне, со всех окрестных деревень к нему направлялись люди с просьбами о помощи. Он слушал их рассказы о голодных буднях и о том, что все собаки, кошки и вороны в селе были давно съедены. Все запасы продовольствия закончились, и люди находились у последней черты. Затем Виллинк посетил портовый город Бердянск, чтобы выяснить, могут ли там швартоваться корабли. Там ему предстала еще более печальная картина: большинство жителей Бердянска тихо сидели по домам, ожидая смерти. Поскольку порт замерз, было понятно, что доставку туда голландских гуманитарных грузов осуществить невозможно.

Перед тем, как направиться в Севастополь, чтобы ознакомиться с положением дел в том регионе, Виллинк отправил телеграмму в Министерство иностранных дел Нидерландов, информируя о серьезности ситуации: «Голод в Запорожье. Положение дел на Украине неописуемо. По обочинам дорог лежат незахороненные трупы; ежедневно от голода умирают тысячи людей; уже есть случаи каннибализма. Это факты. Здесь положение дел хуже, чем в Поволжье. Через месяц эта часть Украины превратиться в огромное кладбище. Запасы закончились - лекарств, продуктов питания, одежды, всего. Мир не знает о происходящем; до последнего времени представители других стран не посещали этот регион. Мы первые, кто может сигнализировать о помощи по всему миру. Шлите помощь как можно скорее: иначе будет слишком поздно, и миллионы людей погибнут [20, file 1136].

Это было первое сообщение от иностранца о том, насколько страшен был голод на Украине. До тех пор мир предполагал, что голодом было охвачено только Поволжье ${ }^{21}$.

В отличие от Бердянска, порт Севастополя оказался способным принимать грузы. В конце февраля Виллинк вернулся в Харьков. В последовавшие за этим месяцы наиболее важные партнеры для проекта по доставке голландской помощи находились в Харькове: Бенджамин Янц (председатель Mennonitische

\footnotetext{
${ }^{20}$ В нем состоял этот план, до сих пор остается неясным. Флейшер, упоминает о «новом плане», а конкретно об использовании парома по Черному морю до Бердянска с тем, птобы не хранить товары на советской территории. Однако это не имеет никакого отношения к поставкам тракторов и депозиту в 5 миллионов золотых рублей.

${ }^{21}$ Квислинг прибыл через две недели после Виллинка.
} 
Wirtschaftsverein ${ }^{22}$, ассоциации, служившей ивтересам меннонитских общин юга России); Видкун Квислинг (посланник Нансена ${ }^{23}$, который только что въехал в свой офис в Харькове) и Алвин Миллер (директор Американской меннонитской помощи). Между тем поставки продовольствия от Американской администрации помоши (AРA) были разгружены севернее Харькова, а для доставки их в Молочанский округ не было поездов.

Март прошел в ожидания. Виллинк телеграфировал в Варну с указанием, чтобы судно с гуманитарным грузом из Голландии следовало не в Бердянск, а в Севастополь, где он был готов встретить помопь. Он позна- комился с Квислингом, с которым они почти подружились. Между тем, по мере того, как ситуация с голодом становилась все более критической, оказалось невозможным доставлять продовольствие из Харькова на юг. Виллинк был поражен как обилием выпечки и элитных продуктов в столице, так и разницей цен в городах и деревнях. Он регулярно проводил консультации с Янцем, Миллером и Ермопенко (исполняюпим обязанности руководителя большевистской Украины), обсуждая с ними организационные моменты планировавшихся восстановительных работ, а также вопросы спасения меннонитов в колониях $[3]^{24}$.

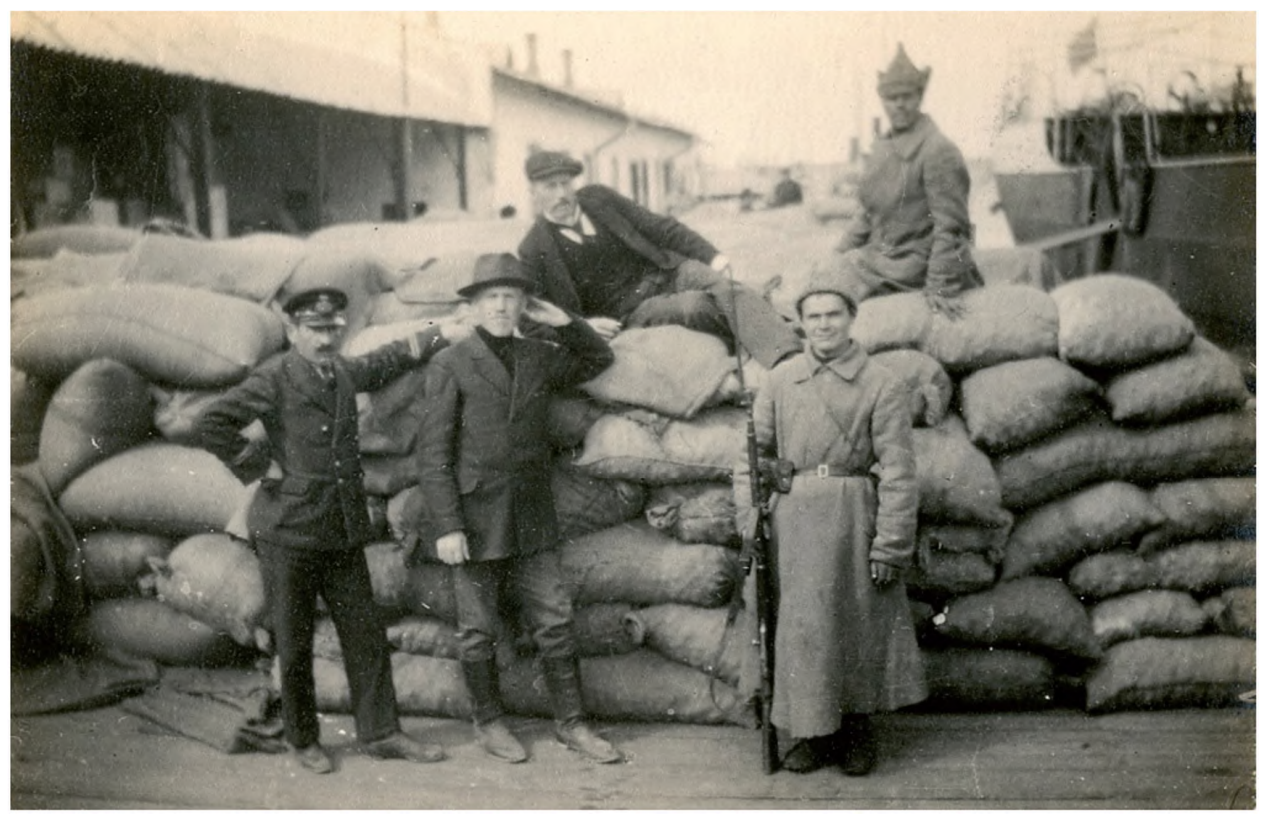

Рис.2. Судно «Болгария» прибыло и было разгружено. Хотя и Виллинк, и Крейбиль делали много фотографий, до наших дней донли лить несколько из них. На этом снимке от

2 апреля 1922 г. Йонгенс лежит на только что выгруженных мешках с припасами, с удовлетворением глядя на них. Человек, стоящий рядом с капитаном, вероятно, Виллинк. Справа - двое из пяти охранников, которые «тпательно выполняли поставленную перед ними задачу», охраняя прибывший груз в порту Севастополя [20]

\footnotetext{
${ }^{22}$ Mennonitische Wirtschaftsverein было рабочнм названдем организапии, созданной для восстановления меннонитских колоний. Янщ вел переговоры с советскими властями в Харькове о получении правого статуса для организации, но они былн против того, птобы дать такой статус «меннонитской» (питай: релнгиозной) организации. В апреле они согласитись на название Verband der Bürger Holländischer Herkunft. Таким образом, Mennonitische Wirtschaftsverein фактически не супествонала как организация, а была, скорее, намерением, упоминавпгемся в корреспонденция между Янщем, Анрухом и Algemeene Commissie voor Buitenlandse Noden. Это название фитурирует в письмах и отчетах Виллинка вилоть до апреля 1922 г.

${ }^{23}$ Квислинт свободно говорил по-русски: он служил военньп атташе Норвежского консульства в Петрограде в 1917 г. Он незамедлительо отправнлся с ознакомителной поездкой в пораженные голодом районы, а затем отправил Нансену тревожные отнеты о голоде. Его опублихованный отчет дает хорошее представление о положении дел ва Украине в марте 1922 г. («La famine en Ukraine», CISR Bulletin 22, 4 апреля 1922 г.). Впоследствии Квислинг войдет в историю как политический лидер Норвегии в период немецкой оккупацик.

${ }^{24}$ Основной темой обсуждений были вопросы представительства MWV и сохранения однородного характера меннонитских колоний. Дайк записял в своем дневнике 3 марта 1922 г.: «Вчера приехял Миллер. Через несколько дней прибудут четыре вагона с продовольствием. Первыми помощь получат дети, больные и наиболее нуждающиеся. Эта организапия функпионлрует независкмо от голландской. Как только прибудет голландкий груз, продовольствие, доставленное Миллером, перевезут в другой район» [3, p. 181].
} 
В конце месяца Виллинк отправился в Севастополь, куда 31 марта прибыла «Болгария», доставившая не только еду, одежду и лекарства из Нидерландов, но и других членов миссии. «Внезапно подошла моторная лодка, - писал он в своих путевых заметках, и я услышал голос, который сказал: «Смотрите, вон г-н Виллинк собственной персоной». Голос принадлежал медсестре Вермаас. Вскоре г-н и г-жа Йонгенс и две медсестры впервые ступили на русскую землю; все они были в отличном здравии». Первая часть пути была позади. Теперь груз нужно было доставить в Лихтенау. Украинские портовые рабочие перенесли его на склады, где он перешел под ответственность нескольких молодых меннонитов, которым была поручена охрана ценного груза. Виллинк смог договориться с руководством Крыма касательно транспортировки: он подписал контракт, по которому неболышая часть продовольствия должна была быть передана голодающим крымским татарам в обмен на разрешение на перевозку груза. Помимо этого, Виллинк согласился выступить с призывом о сборе помощи для татар [20, 1118 , file 147].

Поскольку голландцы оказались первыми иностранцами в Крыму, у них появилась возможность предпринять там ряд коммерческих инициатив, пользуясь хорошей репутацией, которой они заручились благодаря помощи голодающим. Так, через несколько дней Виллинк писал Флейшеру: «Спасите Крым! Голландия у всех на устах; для вашего комитета есть хорошая задача» (отчет Флейшеру от 5 апреля 1922). Затем он написал душераздирающий очерк о страданиях жителей Крыма, региона, который находился за пределами поля зрения западной прессы и гуманитарных организаций, а Флейшер вскоре опубликовал его на страницах Zondagsbode: «... Я видел их, татарские деревни, 80 процентов населения которых были мертвы, а оставшиеся жители тихо лежали в своих домишках, окруженных горами и скалами, в ожидании смерти. В одном доме была мать с двумя детьми; в другом - старуха, единственная выжившая из семьи в семь человек; чуть поодаль - двое молодых парней. Все они лежали, завернутые в цветастые одеяла, на полу своих жалких жи- лищ, в которых кроме них не было ничего, поскольку буквально все было уже продано. Они легли, чтобы заснуть последним сном, ожидая неминуемого конца в тихом смирении... Во всех этих домах, куда припла смерть, царила гробовая тишина. Лишь тусклый свет в красивых темных глазах на их лицах цвета слоновой кости говорил о том, что Смерть еще не забрала их. Благородный татарский народ, эти гордые горцы, умирают среди пробуждающейся природы» (9 апреля 1922 г., «Stervend Berdjansk, stervend Taurië»).

Заключенный с крымскими властями контракт сработал. Груз был доставлен со складов на поезда, которые затем отправились в Лихтенау. Виллинк верно оценил риски транспортировки. В то время, как американские поставки на долгие месяцы застряли к северу от Харькова, голландская помощь прибыла из Севастополя в Лихтенау примерно через неделю. Первые 23 вагона (по 1000 пудов продовольствия в каждом) прибыли 12 апреля. Через несколько дней вагоны были разгружены, и первый груз был распределен между жителями меннонитской колонии 15 апреля, в Великую субботу ${ }^{25}$. Виллинк и его главный помощник и бухгалтер Йонгенс установили жесткую систему распределения помощи: каждая община прислала по два представителя. Степень бедствия в каждой из них была определена заранее, и представители общин получили столько сухих пайков, сколько было необходимо для их выживания в течение двух недель ${ }^{26}$.

Американская помощь была отправлена на месяц раньше, но её хватило лишь для небольшой части населения [13, p. 212-221]. У Миллера было разрешение на доставку продовольственных пайков только в большие меннонитские общины, для которых отправляли пожертвования их американские родственники: в Хортишу, Гальбштад и Гнаденфельд. Первая американская помощь практически не достигала тех, кто жил в сельской местности. Деятельность Американской меннонитской помощи в Молочанском меннонитском округе сводилась к организации бесплатных столовых в поселениях, где воспользоваться ими могли только дети, женщины и наиболее нуждающиеся.

\footnotetext{
${ }^{25}$ В записи от 17 апреля говорится, что голландская помощь обещает больше, чем американская. Так и произошло 22 апреля: «Эти поставки принесут нам больше помощи, чем те, что отправлены Американской администрацией помощи». Второй день Пасхи стал также днем, когда продовольственная помощь от АРА, наконец, была распределена в Поволжье. Очередь Украины получить помощь от АРА придет лишь в мае [1].

${ }^{26}$ Запасы продовольствия на первые 14 дней были установлены в следующем объеме: «бобы 3,5 фунта, мука 2 фунта, рис 1 фунт, стручковая фасоль 2 фунта и сельдь 2 фунта, всего 10,5 фунтов на человека» (3-й отчет Флейшеру, 17 мая 1922 г.).
} 
В то время как голландцы организовали свою работу через расширение деятельности местного Mennonitische Wirtschaftsverein, aмeриканцы создавали отдельные комитеты. Это привело к путанице и напряженности - было неясно, на кого конкретно могли положиться жители Молочанского округа. В конечном счете, именно голландские продуктовые пайки достигли большинства его жителей, и мы можем справедливо заключить, что большинство меннонитов в Молочанском округе были спасены благодаря помощи из Нидерландов ${ }^{27}$.

Сам Виллинк не присутствовал при раздаче продовольственных пайков, поскольку 12 апреля, сразу после прибытия груза в Лихтенау, он отправился в Константинополь. Его финансовые ресурсы были на исходе. Не имея возможности обналичить западные векселя в районах, контролируемых большевиками, он был вынужден отправиться в Турцию. Виллинк прибыл в Константинополь вечером 15 апреля. Длительная процедура проверки привела к тому, что он добрался до таможни слишком поздно, чтобы получить наличные деньги. Более того, таможня закрывалась на два дня. Не падая духом, Виллинк смог попасть в консульство Нидерландов, где и произвел необходимые финансовые трансакции. Уже 28 апреля он вернулся в Лихтенау.

По его возвращении Йонгенс доложил Виллинку, что «ситуация... крайне плачевная, и наша помощь прибыла в самый нужный момент. Люди были на грани отчаяния» [20, 1118 , file 151]. Жители Молочанского округа были глубоко признательны за предоставленную помощь: отчаяние последних недель сменилось возрождением интереса к жизни и духа предпринимательства [13, p. 394]. Наиболее прекрасное выражение этой благодарности нашла Анна Берг, влюбившаяся в Герхарда Хардера, переводчика Виллинка. Берг пристально отслеживала все перипетии, связанные с доставкой голландской помощи, и даже посвятила этому стихотворение.

\section{$\Gamma$-ну Виллинку}

Простите мне мою бесцеремонность, но я должна найти слова, чтобы выразить, сколь глубоко мы вам обязаны.

Иначе мне не будет покоя.

Мы знали лучшие времена, когда царили мир и изобилие.

Но затем наступили темные дни ужаса, губящие жизни и разрушающие надежды. Как будто этого было недостаточно, казалось, болезнь, боль и смерть сговорились погубить наш народ раньше срока. Наступил неурожай, а вслед за ним раздался дрожащий голос голода. Мы обратили к Богу мольбы спасти нас от этой страшной участи, и теперь, как и всегда, Он явился, когда мы уже думали, что все потеряно. Ибо неведомые нам далекие братья услышали наши молитвы и,

\footnotetext{
${ }^{27}$ См. например, записи Дайка от 17 апреля 1922 г. «Голландское продовольствие представляется более перспективньм, чем американская помошь) и от 7 мая 1922 г.: «Американская помощь слишком скудная» [3, p. 190, 193]. Кристиан Крейбель, который отвечал за помощь Молочанскому округу от лица Американской меннонитской помопи, отмечал в своих дневниках (13 и 14 апреля 1922 г.), что Американская администрация помощи (гуманитарная организация Гувера) также раздавала продовольствие, скорее всего, посылки от родственников. Из отчетов Виллинка (2-ой отчет Флейшеру, 5 апреля 1922 г., стр. 2) и заметок на полях в дневниках Крейбеля (в частности, от 17 апреля 1922 г.) следует, что взаимодейстие между ними не всегда пло гладко. Крейбель видел, что Виллинк действовал в тесной связке с MWV и, как следствие, те, кто не был связан с MWV, оставались неохваченными. Тем временем были сформированы комитеты для получения помощи от американщев. Возник риск, что некоторые меннониты будут получать продовольствие с обенх сторон. Крейбель хотел избежать этого и предложил сотрудничество. Он предполагал, что американцы предоставят помощь всему Молочанскому округу. Но Виллинк уже сльшал от Миллера, что тот собирался ограничить американскую помопь Хортищей, Гапбштадом и Гнаденфельдом, обшинами, получаюшими посылки с продоволствием от родственников в Соединенных Штатах. Это означало, что большинство меннонитов Молочанского округа будет зависеть от голландской помощи. Тем не менее, Виллинк был открыт к сотрудничеству, и 7 мая (см. дневники Крейбеля) встретился с американцами за ужином. Однако они не смогли прийти к согласию, поскольку, по словам Вилшикка (3-й отчет, 17 мая 1922 г, стр. 5), американщы настаивали на сохранении своей системы. Это ознацало, что доступа к помощи были лишены люди в возрасте от 15 до 60 лет, а таюже семьи, у которых было две молочные коровы (даже если у них не было никакого другого продовольствия, а к таким относилось 90 процентов меннонитов Молочанского округа). Сотрудничество по американским стандартам означало бы, что те, кто был охвачен Algemeene Commissie Buitenlandse Noden, не получили бы никакой помощи. Списки распределенной помощи и квитанщии $[20,1118$, карта 154, 157] указывают зоны ответственности Algemeene Commissie Buitenlandse Noden. В этих списках нет Гальбштада и Хортицы, но присутствуют все села Молочанского округа. Приведенные в книге Миллера [13, p. 394-408] выражения благодарности имеют отношение только к поселениям за пределами Молочанского округа. (Есть только одно исключение: письмо от жителей Риккенау с благодарностью за организацию бесплатных столовых, стр. 396). В документах $[20,1118 / 14 \mathrm{~d} / 9958,9959,9960]$ содержатся аналогичные выражения благодарности от сел Молочанского округа за голландскую помощь. Более подробная информация о взаимоотнопених между гуманитарнњги усилиями Американской меннонитской помощи, Algemeene Commissie Buitenlandse Noden и Нансена содержится в статье Флейшера [6, 1924, p. 61-78], где он ссылается на офищиальный итоговый доклад украинского правительства. Algemeene Commissie Buitenlandse Noden накормил 22000 человек, Нансен - 6 000, а Американская меннонитская помощь - 24000.
} 
протянув руку помощи, взяли наши жизни в свои ладони. Поэтому я так уверена, что через них Нам ответил Бог.

Жаль только, что их не было с нами, когда каждый получал свою долю.

Здесь - тихий, волнующий вздох, там - крик ликования;

каждый из нас как ребенок

на Рождественской елке.

Из нашей радости выросла надежда, посылаемая сердцем в рай, что Он, Царь Царей, благословит и сохранит вас сейчас и всегда.

Пусть то, что вы сделали для нас сегодня, вернется вам сторицей.

Пусть Бог хранит вашу Родину

от печальной участи, выпавшей России.

Прошу вас, не думайте обо мне дурно

От того, что я говорю вам простое, сердечное спасибо.

Дай Господь вам мира, во веки веков [1, p. 178-179]

Некоторым показалось странным, что в важный момент раздачи продовольственной помощи Виллинк отсутствовал. Кристиан Крейбель, отвечавший за гуманитарную помошь в Молочанском округе от имени Американской меннонитской помощи, пристально следил за деятельностью Виллинка ${ }^{28} .18$ апреля, во время первой раздачи голландской продовольственной помощи, он записал в своем дневнике: «Похоже, голландцев больше интересует бизнес, чем помощь голодающим». Подоплекой этого замечания была напряженность между Американской меннонитской помощью и Mennonitische Wirtschaftsverein, ассоциацией меннонитов Украины, с которой Виллинк тесно сотрудничал ${ }^{29}$.

У Крейбеля сложилось впечатление, что Виллинк ставит коммерческие интересы вышегуманитарных. Эти подозрения были безосновательны. В конще концов, Виллинк вел переговоры о поставке тракторов уже в своих первых контактах с Советами. 17 мая Виллинк писал Флейшеру, что помощь пришла как раз вовремя, чтобы «предотвратить акт отчаяния целого народа, т.е. коллективное бегство... Сейчас, что касается Крыма и Украины, у Голландии на руках все картыр. Он советовал голландским предпринимателям воспользоваться этой возможностью. Проблем с транспортом не будет, поскольку советские власти были хорошо расположены к голландцам. Кроме того, Mennonitische Wirtschaftsverein недавно сменила название на Verband der Bürger Holländischer Herkunft ( $\mathrm{CO} \mathrm{O}$ граждан голландского происхождения), который стремился привлечь Algemeene Commissie voor Buitenlandse Noden к стимулированию торговли с Нидерландами. Теперь, когда кризис изза голода был предотвращен, а первый посевной материал роздан и посеян, пришло время посмотреть немного в будущее. Двумя неделями позже Виллинк писал: «По реакции трех представителей советского правительства я заметил, что мое требование о внесении депозита в золотых рублях явилось для них новым взглядом на проблему; поэтому крайне важно как для меннонитских общин, так и для нашего Комитета, a возможно - с прицелом на будущее - и для всех Нидерландов - стать первыми в этом деле, которое также является единственным эффективным способом спасти местных меннонитов от неминуемого разорения в следующем году» (в письме Флейшеру, в письме родителям, 30 мая 1922 г.).

С целью сохранения полученного Голландией преимущества Виллинк отправился в Москву вместе с представителями Нансена, чтобы договориться с гуманитарными организациями из Швейцарии, Эстонии и Чехословакии о том, что он должен стать координатором всей иностранной помощи Украине. На тот момент у него была сильная позиция, поскольку он уже обладал необходимыми знаниями о местной ситуации, в то время как другие иностранные представители только что прибыли (секретное письмо Флейшеру, 27 мая 1922 г.). Затем Виллинк отправился в Крым, где он был готов выступать в качестве представителя Нансена (Письмо Флейшеру, после 5 июля 1922 г., но до 18 июля 1922 г.). Там в начале июня он встретил второй корабль с гуманитарным грузом из Нидерландов.

\footnotetext{
${ }^{28}$ Всю помощь меннонитским общинам в России от лица Американской меннонитской помощи в Поволжье, Сибири и на Украине координировал Алвин Миллер. Помощь детям и раздачу одежды в Молочанском округе он оставил Крейбелю [13, p. 332-334, 337-338].

${ }^{29}$ В письме Йонгенса 10 (17 июня 1922 г.) говорится о том, что Виллинк представляет Красный Крест и Нансена в Феодосии"; во 2-м отчете (21 марта 1922 г., стр. 2), среди прочего идет речь о предстоящем создании голландской корпорации. Ожидалось, что к ней будут применены более мягкие критерии в отношении собственности на землю, в результате чего, благодаря голландскому вмешательству, меннониты смогли бы сохранить больше земли. Это увеличило бы их пансы на выживание. Примерно в то же самое время Анрух пытался найти немецких инвесторов в Берлине (письмо Анруха Фризену, 3/7/1922, СМВС Janz файл 09).
} 


\section{Интермеццо в Харлеме}

В середине июля 1922 г. Виллинк отправился в Нидерланды, чтобы отчитаться о своей деятельности. Вскоре после этого голландские медсестры также покинули Молочанский округ. 28 июля Виллинк представил свой отчет на заседании Algemeene Commissie voor Buitenlandse Noden в Харлеме. Члены комитета были изначально настроены негативно, поскольку в последние месяцы они не получали достаточной информации от участников экспедиции: первый отчет Виллинка не дошел, другие были доставлены с опозданием или все еще были в пути. Таким образом, члены комитета были готовы задать Виллинку ряд вопросов, а также получить отчеты, которые с ним передали Йонгенс и медсестры. Они также хотели пообщаться с медсестрами напрямую, для чего те были приглашены на заседание 4 сентября.

Виллинк описал построенную им организацию: головной офис в Севастополе, с десятью сотрудниками и регулярной связью с Западной Европой через курьера, который отправляется в Харьков каждые две недели. Хотя сообщение внутри России было затруднено, правительственные чиновники и обыкновенные граждане были настроены на сотрудничество. По его словам, качество отправленных грузов было превосходно и во всех отношениях отвечало ожиданиям. Взаимодействие с американцами было непростым из-за тех правил, которым они хотели следовать. Виллинк назвал их сторонниками принципов, Prinzipienreiter. Люди предпочитали голландскую помощь, потому что голландцы были более доступными. Работа была разделена между различными организациями: американцы открывали бесплатные столовые для самых бедных, тогда как голландцы раздавали людям продовольственные пайки, которые те могли съесть у себя дома. Виллинк тесно сотрудничал с местными меннонитскими организациями, в то время как американцы создавали свои собственные. По словам Виллинка, помощь от Algemeene Commissie Buitenlandse Noden достигла 60 деревень (около 35000 жителей) в Молочанском округе, помимо 17000 человек на Хортице ${ }^{30}$ и 8000 человек в Крыму. То, какой эффект доставка помощи оказывала на моральное состояние людей, отметил Виллинк, было, вероятно, еще более важно, чем ее материальный аспект. Отчаяние и фатализм отступали, и жители меннонитских колоний начали снова проявлять инициативу. Голод прошел, а доставленные из Голландии семена (при нормальном урожае) обеспечат производство достаточного количества продовольствия.

Виллинк добился многого. Но он практически постоянно был в разъездах. По сути, работой организации руководил Йонгенс. Действительно, Йонгенс в письмах часто жаловался на отсутствие Виллинка и на то, что он не знал, где тот находится. Например, однажды Виллинк не выдал разрешения на критически важную раздачу помощи и не отвечал на запросы Йонгенса. Тогда Йонгенс отправился в Севастополь в надежде найти его там. Ему повезло: Виллинк действительно был там, выздоравливая после дизентерии. Йонгенс получил разрешение на то, чтобы ускорить раздачу помощи.

И Виллинк, и Йонгенс отметили, что работы для медсестер не было, и те согласились вернуться домой, так и не оказав кому-либо медицинскую помощь. 4 сентября медсестры сами выступили перед комитетом. Хотя они считали Виллинка «руководителем», за все эти месяцы они встретились с ним только дважды. У него не было указаний относительно работы, которую они должны были выполнять, и он не приложил никаких усилий, чтобы выработать какую-либо стратегию. Поэтому им пришлось обратиться к Йонгенсу. Вначале у них были хорошие отношения с Йонгенсом, но затем у него стали проявляться нотки превосходства. Он якобы не поддерживал их предложения о помощи, утверждая, что женщины «слишком чувствительны к окружающим их страданиям». Медсестры, в свою очередь, считали Виллинка крайне неотзывчивым: он делал свою работу «хорошо, но без любви. Например, его раздражали дети, просящие милостыню. Местные жители называли его жестким». Они же утверждали, что его жена держала себя так, словно она была королевой деревни, а ее поступки при этом были похожи на поступки ребенка.

Флейшер с такой оценкой согласился. Йонгенса он считал компетентным, но довольно ограниченным. При этом Флейшер выразил удивление в отношении медсестер. В инструкциях комитета четко указано, что все члены миссии были равны и между ними не предполагалась иерархия. Он обвинял медсестёр в отсутствии инициативы, право на которую было прописано в инструкции. Флейште-

\footnotetext{
${ }^{30}$ Здесь, вероятно, Виллинк преувеличивал: списки распределения помощи $[20,1118$, files 154,147$]$ не содержат свидетельства доставки помощи за пределами Молочанского округа. Сравн. $[15$, с. 76$]$ для получения представления о важности голландской помощи с точки зрения ураинских властей.
} 
ра удивило, почему женщины не навестили его в Крыму и Харькове, где также было много работы.

В ответ на высказанные претензии медсестры утверждали, что не до конца поняли инструкщии и рассматривали Виллинка руководителем миссии. Вопреки всем оговоркам, женщины расценили экспедицию как в целом успешную: «Распределение помощи хорошо организовано и отлично работает. Американские столовые великолепны, но в целом получатели вполне довольны нашей системой распределения, которая столь хорошо отвечает их склонности к индивидуальности и домашнему уюту» [20, 1118, file 19].

Несмотря на прозвучавшую в адрес участников миссии критику, Виллинк и Йонгенс действительно преуспели в создании хорошо управляемой организации: Йонгенс создал рациональную систему распределения помощи, а Виллинк выстроил бесперебойную систему транспортировки ${ }^{31}$.

Возвращение в Россию: новые обстоятельства

В конще сентября 1922 г. Виллинк снова отправился в Россию, на этот раз на поезде через Балканы, а затем через Варну на корабле в Севастополь, где он возобновил свою деятельность. Теперь, когда голод был позади, встал вопрос, в каком направлении следовало бы сконцентрировать усилия в оказании дальнейшей помощи. В конще месяща состоялось заседание украинского меннонитского Verband der Bürger Holländischer Herkunft (Союза граждан голландского происхождения, Союза потомков голландских выходцев), на котором обсуждались два варианта: эмиграция или реконструкция [21, р. 175-182]. Союз рассматривал предложение о том, чтобы беженцы, которые в конце 1921 г. переехали из Поволжья на Украину, поскольку дела там обстояли несколько лучше, эмигрировали в Канаду. Поскольку у этих беженцев не было своей земли, их пропитание целиком зависело от других людей. Несколько тысяч из них первоначально выразили заинтересованность в отъезде, и даже был составлен список желающих. Но когда пришло время принимать окончательное решение, большинство решили остаться, сочтя, что их перспективы на Украине заметно улучшились. Виллинк писал Флейшеру: «Вот типичный пример изменчивого настроя колонистов. Как вы знаете, несколько тысяч человек выразили готовность эмигрировать. Были составлены и утверждены списки и т. д. Как мне сказал г-н Йонгенс, некоторое время назад пришла телеграмма с вопросом, можно ли перевезти 3000 эмигрантов в Либаву, где они смогут сесть на корабль. Однако теперь оказывается, что болышинство этих «страстных эмигрантов» более не склонны никуда уезжать исключительно потому, что сейчас положение их несколько улучшпилось благодаря нашей и американской помощи. Вот так опошляются вопросы жизни и смерти!» [20, 1118/031].

Это не помешало Янцу вести дальнейшие переговоры с представительством Канадской тихоокеанской железной дороги в Москве, которая предлагала желающим «эмиграционные пакеты». Казалось, что деньги не играли в этих переговорах большой роли до тех пор, пока не приходило время заключать конкретные соглашения. Виллинк считал подход Янца «крайне слабым» и называл весь этот проект «дилетантским». Поэтому он дал понять Янцу, что «эта эмиграционная схема не пользуется [у них] поддержкой, и что ему не следует рассчитывать на какое-либо содействие) с его стороны ${ }^{32}$.

Меннонитский союз на Украине Verband der Bürger Holländischer Herkunft поддерживал переселение внутри Украины и реконструкцию. Флейшер и Виллинк пообещали собрать 50000 гульденов на закупку посевного материала, а Verband der Bürger Holländischer Herkunft подумывал о привлечении западных кредитов в форме акций по цене 10 гульденов / долларов за штуку на общую сумму в один миллион долларов. Виллинк был против этой затеи. «Какая наивность...», - писал он. И далее: «Такие базовые вещи, как бюджет и план

\footnotetext{
${ }^{31}$ Виллинка не зря прозвали «Летучим голландцем» [20, 1118/020: «Kort verslag van de reis naar Berlijn door T.O. Hylkema 16-20 juni 1924,1]. Хилкема был в Берлине для проведения консультаций с Анрухом. П.К. Хьеберт, председатель Центрального комитета меннонитов, который был на Украине в апреле и мае 1922 г., также оказался в Берлине и присоединился к ним. Они так оценили голландскую помощь: «Появление голландцев, которые оказались первыми и которые появились как раз в тот момент, когда люди видели только растущее число братских могил, относится к тем незабываемым историческим моментам, о которых будут рассказывать наши правнуки, благодаря которым (согласно письмам) во многих домах каждый день раздаются молитвы и слова благорадности тем, кто прислал помощь. Виллинк организовал помощь быстро и энергично, именно поэтому слава досталась ему, тогда как американцы замешкались, хотя и находились в регионе уже долгое время. Ему дали прозвище «Летучий голландец». Так же называли его машину, заседания комитета и регламент: машины с продовольственной помощью приезжали всегда в назначенное время. Благодаря этой помощи, тысячи людей были спасены от голодной смерти».

32 Здесь также заинтересованность проявили 4000 человек из Хортицы [22, p. 97].
} 
расходования средств, план по выплате процентов и погашению кредита, гарантии даже не упоминаются. Все это представляется здесь лишним» $[20,1118$, file 12 , № 5575]. К конщу октября организация «Американская меннонитская помощь» уже поставила 26 тракторов марки «Фордзон», и Союз потомков надеялся, что теперь Algemeene Commissie Buitenlandse Noden обеспечит необходимые семена ${ }^{33}$.

Однако теперь, когда голод был позади, отношение советского правительства изменилось. Большевистская власть стремилась полностью подчинить западные гуманитарные организации своей политике; в противном случае этим организациям предлагалось как можно скорее покинуть страну. Так, например, советское правительство установило даты окончания контрактов с Американской администрацией помощи и с организацией Нансена. Помгол был преобразован в организацию по реконструкции и восстановлению. В октябре Виллинк отправился в Москву для проведения консультаций с коллегами и с большевистскими властями. Ему стало очевидно, что гуманитарные усилия будут завершены к 1923 г. Однако он не исключал, что были еще другие возможности для участия в процессах восстановления.

В Москве он принял участие во встрече c 800 представителями Помгола во главе с председателем ВЦИК Калининым, посмотрел балет в Большом театре («Корсар»), сходил в цирк и 7 ноября присутствовал на параде на Красной площади в честь пятой годовщины революции. Он стоял в пяти метрах от Ленина, который был описан им следующим образом: «В черной зимней куртке европейского покроя и серой жокейской кепке на голове. Он стоял, приветливо улыбаясь, и казалось, будто он простой зритель, подъехавший на машине. Перед трибуной, в группе из двадцати офицеров, стоял Троцкий, одетый в военную форму и постоянно отдающий честь».

Находясь в Москве, Виллинк познакомился с Фрицем Куйпером, сыном священника из Амстердама, который направлялся в Казань, чтобы предложить там помощь от лица голландских студентов. Он также дал интервью немецкому журналисту Полу Шефферу, корреспонденту газеты Berliner Tageblatt. Шеффер, как писал Виллинк, «неплохо говорит по-голландски, так как он долго жил в нашей стране во время войны. Он приехал в Россию, кажется, в прошлом году, и его статьи о России в Tageblatt, вероятно, лучшее из того, что было опубликовано по этой теме. Он остроумный собеседник. По моим подсчетам, ему нет еще 40».

Единственная договоренность, которой Виллинк достиг в Москве, касалась доставки топлива в Молочанский округ на сумму 10000 гульденов. На этом было сосредоточено его внимание в последние месяцы 1922 г. Встретив Рождество в Харькове, Виллинк составил свой заключительный отчет. В начале марта он вернулся в Нидерланды, где 8 марта 1923 г. он ещё один раз отчитался перед голландским комитетом.

\section{Завершение экспедиции?}

Виллинк доложил членам комитета, что урожай озимых в Молочанском округе не удался. Оставалась большая потребность в посевном материале, который можно было закупить у украинского правительства. Американцы поставили 49 тракторов, но местные жители продолжали надеяться на получение семян из Нидерландов. Гуманитарная экспедиция могла быть официально завершена 1 июля 1923 г., а ее оставшиеся участники освобождены от своих обязанностей. Но поскольку оставался еще большой дефицит одежды и обуви, такую помощь следовало продолжать. Он утверждал, что первоначальная цель Gemeentedagbeweging - укрепление и углубление контактов с единоверцами в новой России - была достигнута. Но означало ли это конец экспедиции? И каковы должны были быть дальнейшие шаги?

Виллинк начал с оценки экономических перспектив советской Украины. Он сообщил: «С восстановлением нормальных условий желание покинуть страну ослабевает. Частная собственность на землю отменена, и это уже вряд ли изменится, но семьи могут арендовать землю по долгосрочным контрактам (сроком на 24 года) - 16 десятин или, если в семье более шести человек, даже 32 десятины - и этого достаточно для относительного благополучия. Сыновья могут перенимать права аренды у родителей, но субаренда запрещена: все должны обрабатывать землю сами. Вместе с тем дома считаются личным имуществом и могут продаваться».

\footnotetext{
${ }^{33}$ Письмо Флейшеру от 11 ноября 1922 г. [20, 1118, file 031]; Toews J. [22, p. 96-100], дает немного более полное представление о действиях Янца; именно отсгода, главным образом, складывается впечатление, что он сделал несколько логистических просчетов - например, в том, что касалось методов работы Канадской тихоокеанской железной дороги, стоимости транспортировки в Либаву и проживания - а не то, что интерес к эмиграции резко упал из-за улучшения положения колонистов.
} 
Таким образом, можно было ожидать, что меннониты будут в состоянии погасить любые займы. Местные органы власти были настроены благожелательно, но они расторгли контракты с западными гуманитарными организациями, поскольку у них не было ресурсов, чтобы продолжать предоставлять им ранее оговоренные услуги, такие как проживание и транспорт. Комитет поручил Виллинку достичь договоренности с местными органами власти, чтобы те позволили голландцам продолжать оказывать помощь без затрат для советского правительства. Таким образом они могли бы развивать тот задел, который был создан за последние несколько лет. Они выделили Виллинку 8000 долларов в качестве займа для Verband der Bürger Hollāndischer Herkunft на покупку посевного зерна [20, 1118/019].

Виллинку, похоже, понравилась эта идея, и он снова отправился в Россию, на этот раз с прицелом на развитие бизнеса. В 1923 г. украинское правительство предоставило ему право на освоение участка земли. Он нашел несколько голландских финансистов, в основном членов правления Банка Твенте, которые согласились инвестировать 75000 долларов. Из этой суммы Виллинк вложил 10000 долларов своих собственных средств. В качестве главы (на общественных началах) голландско-российского синдиката по освоению земель он получил концессию на 1200 десятин земли на территории Украины неподалеку от Риккенау [15, с. 198-202]. Синдикату предоставлялось полное право на использование этой земли в течение 12 лет. Взамен он должен был выплачивать 25 процентов урожая в качестве арендной платы, или минимум 13,5 пудов с десятины. Предоставленная синдикату земля была в довольно плачевном состоянии и требовала дополнительных усилий, чтобы снова стать пахотной. Виллинк назначил нескольких меннонитов в качестве постоянных сотрудников, а также нанял временных работников из соседних русских деревень. В первые годы концессия была убыточной, потому что стоимость зданий и персонала была слишком высока для такого небольшого участка земли. В последующие годы урожай был ниже ожидаемого. В 1926 г. Виллинк пригласил сельскохозяйственного эксперта из Голландии оценить жизнеспособность проекта, и его заключение оказалось положительным: если Виллинк продаст свою машину и сократит постоянный штат, конщессия может выйти на прибыль в 1928 г.

Одновременно Виллинк изучал возможность приобретения земельной концессии на
Кубани, в болотистой местности на Азовском море, территория участка предполагалась в сто раз больше украинской. Для этого предприятия ему нужны были новые источники финансирования, поскольку его существующие партнеры по синдикату явно не испытывали интереса к этому проекту. В интервью «Algemeen Handelsblad» Виллинк заявил, что ищет инвесторов для многообещающего проекта в местности, богатой рыбой и идеальной для строительства заводов. Но в это время на политическом горизонте начали собираться темные тучи. Внутри партии большевиков шла ожесточенная дискуссия о земельной реформе: следует ли продолжать принятую в 1921 г. либеральную политику или в конечном итоге землю следует коллективизировать. Осознавая нестабильность политического климата и потенциальную угрозу их экономическим перспективам, предприимчивые меннониты из Молочанской колонии начали искать варианты эмиграции.

Между 1923 и 1925 гг. эмиграция из Молочанского округа наконец набрала обороты. Нидерландский порт Роттердам стал важным пересадочным пунктом на пути меннонитов в Южную Америку. 1 июня 1924 г. несколько украинских меннонитов появились на праздновании Дня Святой Троицы в Роттердамской меннонитской церкви. Они слышали, что прихожане этой церкви участвовали в помощи голодающим в России, и хотели выразить им свою благодарность. Когда при дальнейшем общении украинские меннониты начали описывать пережитые ими тяготы, их голландские собратья почувствовали «необъяснимую связь» с ними. Эта встреча положила начало более активному участию роттердамской общины в эмиграционном движении. Саймон Гортер, священник этого прихода, учредил Hollands Doopsgezind Emigranten Bureau (Голландское бюро по эмиграции меннонитов) в составе Algemeene Commissie Buitenlandse Noden, который финансировал новую структуру из денег, оставшихся от сбора помощи для России. В последующие годы около тысячи эмигрантов прибыли в Роттердам, где они нашли временную поддержку [25, p. $12-$ 16]. Со временем Hollandsch Doopsgezind Emigranten Bureau возьмет на себя функции Algemeene Commissie Buitenlandse Noden в качестве основного связующего звена для этой диаспоры. Когда в конще 1929 г. И. Сталин навсегда закрыл границы для эмиграции, Hollandsch Doopsgezind Emigranten Bureau продолжало собирать средства для поддержки единоверцев, оставшихся в Советском Союзе. 


\section{За завесой молчания}

Окончательно победив во внутрипартийной борьбе, в 1928 г. Сталин приступил к реформированию сельского хозяйства в точном соответствии с худшими опасениями: вся работа на селе должна была осуществляться в колхозах, и все крестьяне должны были служить государству. Те, кто сопротивлялся, обязаны были платить повышенные налоги. Поскольку на практике эти налоги зачастую превышали фактический урожай, независимые фермеры были вынуждены продавать свое имущество и дома. Когда в 1932 г. плохой урожай привел к новой вспышке голода на Украине, Сталин приложил огромные усилия, чтобы сохранить этот голод в секрете ${ }^{34}$. Сталин накрыл Украину «завесой молчания», запретив журналистам въезжать туда и выезжать оттуда. Но даже в этой завесе обнаружились бреши, через которые просачивалась информация о том, что происходит. Одним из источников этой информации была община меннонитов. В своем собственном кругу меннониты предупреждали о надвигающемся голоде с лета 1932 г. В декабре 1932 г. в печати стали появляться письма меннонитов, в которых они сообщали, что им нечего есть и молили о помощи. Созданное Гортером бюро Hollands Doopsgezind Emigranten Bureau немедленно выступило с инициативой организации голландской помощи, собрав около 34000 гульденов для закупки продовольственных пайков (сумма взята из отчетов, опубликованных в De Zondagsbode, 1932-1934 гг.).

Рейн Виллинк также чувствовал себя обязанным предпринять какие-то шаги. С декабря 1932 г. он разъезжал по Нидерландам с выступлениями о своем опыте «основного представителя покойного Фритьофа Нансена на юге Украины и в Крыму во время голода 1922-1923 гг.» Действия Виллинка привели к противостоянию с Гортером, который открыто дистанцировался от него в прессе. Эти разногласия привлекли внимание организации, курирующей благотворительные акции, которая сочла действия Виллинка подозрительны- ми. Она сообщила об этом своему контакту в голландской полиции, комиссару маленького городка Кулемборг. Хотя в архивах нет свидетельств о наличии каких-либо доказательств или о проведенном расследовании, комиссар полиции выдал несколько предупреждений против запущенной Р. Виллинком кампании по сбору помощи. Последний тут же объявил, что он отказывается от своего проекта, и призвал людей поддержать работу бюро Hollands Doopsgezind Emigranten Bureau. Таким образом, связанная с Россией карьера Виллинка бесславно завершилась ${ }^{35}$.

\section{Заключение}

Деятельность и отчеты Виллинка свидетельствуют о непрерывном участии голландцев в поддержке меннонитских колоний Молочанского округа в период между 1921 и 1938 гг. Создание в 1921 г. Algemeene Commissie Buitenlandse Noden привело к оказанию помощи голодающим в 1922 г., помощи в возрождении экономики в 1923 г. (в форме займов на посевной материал и акций), формированию в 1924 г. Hollands Doopsgezind Emigranten Bureau (как подразделения, занимающегося эмиграцией (через Роттердам), концессии Виллинка в Риккенау с 1923 по 1929 гг. и организации помощи голодающим в 1932 г. силами Hollands Doopsgezind Emigranten Bureau. По сравнению с помощью меннонитам со стороны североамериканских организаций, вклад голландцев был скромным. Тогда как Центральный комитет меннонитов в 1920-х гг. оказал поддержу русским меннонитам на сумму 2,5 милн дол., голландская помощь составила примерно одну десятую часть этой суммы. В 1920$\mathrm{x}$ гг. на помощь голодающим, содействие в восстановительных процессах и деятельность Hollands Doopsgezind Emigranten Bureau было собрано 237000 гульденов, к которым синдикат Виллинка добавил 75000 долларов. В период с 1929 по 1938 гг. организация Hollands Doopsgezind Emigranten Bureau собрала около 30000 гульденов непосредственно для жертв голода 1932-1934 гг. в Молочанском округе

\footnotetext{
34 Частирто по тем же причинам, по которым Ленин хотел бы замолчать голод в 1921 г., а именно потому пто это представило бы только что начатые им крупные реформы в плохом свете. Он хотел избежать повторения шквала негативных материалов в иностранной прессе, случившегося в 1929 г., когда 10000 меннонитов отправились в Москву, чтобы заставить его позволить им эмигрировать, поскольку они не хотели стать жертвами коллективизации.

${ }^{35}$ Информации о Гортере в «Vaderland» от 20 декабря 1932 г. и 1 января 1933 г.; 25 февраля 1933 г.; 29 февраля 1933 г.; 9 мая 1933 г. Информация об отказе Виллинка от своего проекта в «Tribune» от 17 мая 1933 г.; «Vaderland» от 2 июня 1933 г. Сведения о Кулемборге в «Algemeen Handelsblad» и «Tribune» от 2 июня 1933 г. В полицейском архиве Кулемборга содержатся полные материалы дела, в которых нет ни одного упоминания каких-либо доказательств недобросовестности Виллинка (Regionaal Archief Rivierenlanden 088, опись 405 файл 526). Возможно, Гортер опасался, что повышенный интерес прессы привлечет внимание большевиков и поставит под угрозу его собственную кампанию. Но нельзя исключать и вероятность того, что Гортер просто недолюбливал Виллинка за его критическое отношение к русским меннонитам в 1920 -е гг.
} 
$[13$, p. 330]. В финансовом обзоре сообцается, что с 29 ноября 1929 г. по 31 мая 1930 г. было собрано в общей сложности почти 250000 гульденов, но эти средства предназначались для развития колоний, созданньг русскими меннонитами, эмигрировавпими в Южную Америку. Болњпитнтво из них эмигрировали из Сибири, а не Украины.

Изначально и Флейшер, и Виллинк имели гораздо более амбицнозные планы. Флейпер надеялся убедить влиятельных предпринимателей из числа голландских меннонитов вложить миллшон гульденов в украинские колонии. Он планировал использовать эти деньги для более крупномасштабньх усилий по реконструкции весной 1922 г. с привлечением специалистов по сельскому хозяйству, тогда как Виллинк вел переговоры с Ермощенко о возможности получить всю территорию Молочанского округа в сельскохозяйственную концессию. Однако инвесторы не хотели брать на себя риски без гарантий со стороны голландского или украинского правительства. Поскольку ни то, ни другое правительство не хотело давать гарантии, после лета 1922 г. от столь амбицсозных планов притлось отказатъся $[20,1118 / 9 \mathrm{a}, 9 \mathrm{c}]$.

В конце 1922 г. Флейшер обратился к богатым голландским фермерам-меннонитам с призывом вложиться в реконструкцию путем покупки акций Verband der Bürger Holländischer Herkunft по цене 10 гульденов за акцию. Он надеялся продать не менее 10000 акций, однако год спустя было продано только около $1600[20,1118 / 14 \mathrm{~d}, 15 \mathrm{a}]$.

Тем временем Вилливк сумел получить в конщессию пусть и не 100000 десятин Молочанского округа, как он первоначально рассдитывал, но 1200 десятин в Риккенау. Он надеялся, что, если это концессионное соглашение окажется успешным, он сможет его распирить. Однако в 1926 г. его концессия все еще была убыточной, а инвесторы сочли политический климат слишком рискованным, ттобы ввязаться в новую авантюру на Кубани. Виллинк окончательно вернулся в Нидерланды в 1929 г. [15, р. 198-199; 20, 1118/115].

Замечание Крейбеля о том, что голландцев больте интересовал бизнес, чем помоць голодаюшкм, следует понимать в более штироком контексте. Антибольшевистский настрой американтев заставлял их сосредоточиться на помощи голодаюпим и эмитрации. С другой стороны, голдандщы сконщентрировали свои усилия на помопи не только эмитрантам, но всему населению, у которого отсутствовала эмиграпионная перспектива. Голландцы заняли прагматичную и реалистичную позицню по отнопению к большевикам, предполагая, что те останутся у власти, но одновременно не исключая возможность епе одной смены режхма. Они думали о сотрудничестве, объединяющем украинских меннонитов и больпевистскую власть. Это соответствовало перво-

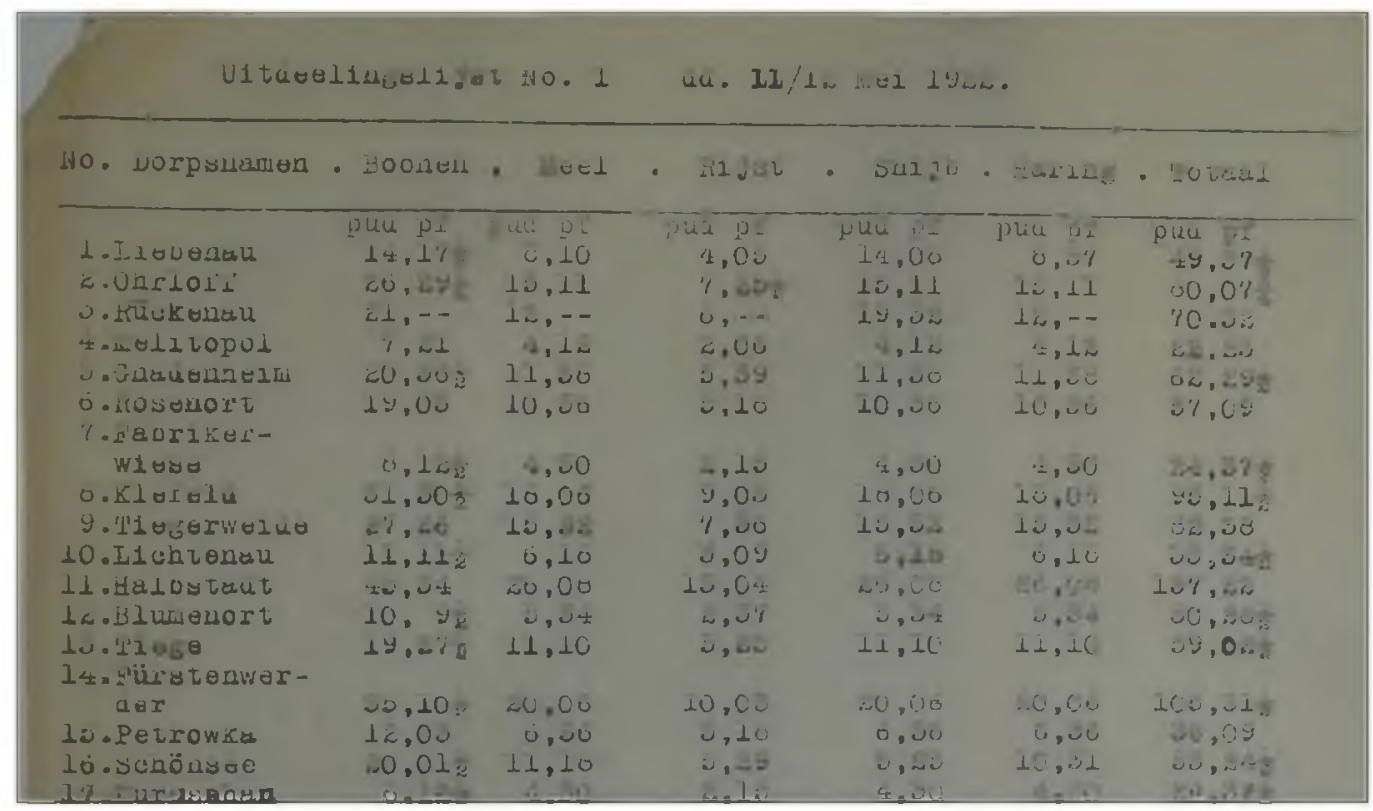

Рис.3. Иввестиции в реконструкцию. Шо спискам квитанций, среди прочего, можно вычислить приблизительно 70 деревень, получавшвх помощь от Algemeene Commissie Buitenlandse Noden. На фото: отчет о распределенин семян 24 апреля 1922 г. (Stadsarchief Amsterdam) 
начальным намерениям Gemeentedagbeweging: возродить и укрепить контакты между голландскими и русскими меннонитами.

К сожалению, политическая и социально-экономическая ситуация в советской
Украине оказалась слишком сложной и непредсказуемой. В этой связи интуиция североамериканских и голландских инвесторов, которые не доверяли большевикам, оказалась верной.

\section{Bibliography}

1. Diary of Anna Baerg, 1916-1924. Winnipeg, 1985.

2. Diary of C. E. Krehbiel 1922-1923. Mennonite Archive, Kansas, Ms 11.

2/1.Doopgsgezind Jaarboekje 1931, Assen, 1930, p. 26-27.

3. Dyck, P. Troubles and Triumphs. Excerpts from the Diary of Peter J. Dyck 1914-1924. Springstein, Manitoba, 1991.

4. Fleischer, F. De Doopsgezinde Geineente Winterswijk. Gedenkschrift uitgegeven ter gelegenheid van het tweehonderdjarig bestaan van het kerkgebouw opgesteld. Winterswijk, 1911. 1922.

5. Fleischer, F. Ons hulpwerk in Oekraine en de Krim,

6. Fleischer, F. Ons hulpwerk in Oekraine en de Krim. DG Jaarboekje, Assen, 1923-1924.

7. Gregory, P. Before Command. An Economic History of Russia. Princeton, 1994.

8. Groeneveld, S. Van Elspeet naar Mennorode. Hoe een broederschapshuis voortbouwt. Hilversum 2000.

9. Hosking, G. Russia and the Russians. A History. Cambridge Mass, 2001.

10. Huebert, H. Events and People in Mennonite History and the People That Made Them Happen. Winnipeg, 1999.

11. Hylkema, T.O. De geschiedenis van de Doopsgezinde Gemeenten in Rusland in de oorlogsjaren 1914 tot 1920 . Giethoorn, 1920.

12. Klippenstein, L. The Selbstschutz: A Mennonite Army in Ukraine 1918-1919. Вопросы германской истоpuu, 2007, p.175-205.

13. Miller, O. Feeding the Hungry. Russia Famine 1919-1925. Scottdale, 1929.
14. Neufeld, D. 'Dietrich Neufeld's A Russian Dance of Death", Revolution and Civil War in the Ukraine. Scottdale, 1977.

15. Ostasheva, N. V. (Осташева, Н. B.). Na perelome epoch (На переломе эпох). Moskow, 1998 [m Russian].

16. Patenaude, B.M. The Big Show in Bololand. The American Relief Expedition to Soviet Russia in the Famine of 1921. Stanford, 2002.

17. Patterson, S. Makhnovists and Mennonites: Intersecting Histories, Unacquainted Narratives. Lecture Katherine Friesen Centre, December 2013. URL http:// criticalconversation.wordpress.com/2013/11/

18. Quisling, V. La famine en Ukraine. CISR Information, No. 22, Genève, 1922.

19. Smele, J.D. The 'Russian' Civil Wars 1916 - 1926.

Ten Years That Shook the World. London, 2016.

20. Stadsarchief Amsterdam (Netherlands, Amsterdam), invrntory 1118,1136 , files $152-153$.

21. Toews, J. Union of Citizens of Dutch Lineage in Ukraine (1922-1927). Mennomite and Soviet Documents. Fresno, 2011.

22. Toews, J. Lost Fatherland. The Story of the Mennonite Emigration from Soviet Russia, 1921-1927. Scottdale, 1967.

23. Unruh, H. Fügungen und Führungen. Benjamin Heinrich Unruh 1881-1959. Detmold, 2009 (HU).

24. Willink, B. Heren van de stooin. De Willinks, Winterswijk en het Twents-Gelders industrieel patriciaat 1680-1980. Zutphen, 2006.

25. Woerden-Surink, J. van. Hollands Doopsgezind Emigranten Bureau, 1924-1940. Proponentsscriptie Seminarium Algeinene Doopsgezinde Sociëteit. Amsterdam, 1999. 